\title{
Problematics of Technical Preparation and Constraints in the Spelling System of Madurese Language
}

\author{
Ali Badrudin*, Akhmad Sofyan \\ Faculty of Humanities University of Jember, Jl. Kalimantan No.37, Krajan Timur, Sumbersari, Kabupaten Jember, Jawa Timur, \\ Indonesia, Post Code 68121
}

A B S T R A C T

\begin{abstract}
Madurese language faces an ironical condition where, as a widely-spoken local language at present, it does not have any standardized spelling which is hardly accepted by linguists of Madurese language. In addition, the spelling problem is a basic way to develop and construct a language. Literally, the spelling of Madurese language in 2012 is a revision from the spelling of BM (Bahasa Madura) in 2003 by the users of the language who thought that the language is hard to use. Due to this reason, many observers of Madurese language such as writers, men of letters and cultural observers suggested to simplify the use of Madurese language's symbols. The method that is used in this research is a descriptive qualitative. The data collection was done by in depth interview circumtantially with the observers of Madurese language who are specifically experts in three dialects (Sumenep, Pamekasan, and Bangkalan).
\end{abstract}

A R T I C L E I N F O

Paper type:
Research Article
Article history:
Received: 1 October 2018
Revised: 11 December 2018
Accepted: 11 December 2018
Keywords:
- Madurese
- Standardized
- Spelling
- Symbol

\section{Introduction}

Bahasa Madura (BM) or Madurese language is a local language which is used as a medium of daily communication by Madurese people and those who live in other small islands around the area or in other areas throughout Indonesia. BM occupies the fourth of thirteen local languages in Indonesia (Lauder, 2004). However, it does not have a Standardized Spelling for Madurese Language (Ejaan Bahasa Madura Baku or shortened EBM), which is mostly caused by the act of dichotomy or lack of understanding in unity from its observers (Sofyan, 2007a). It results in the composition of EBM of Bahasa Madura which was held in 1973 through a small discussion in Pamekasan at 28-29 of May 1973, and until today it has not been officialized (Sofyan, 2007a).

Other opinion shows that the practicioners of BM regard that the researchers do not understand the reality of BM in every day life in society. On the other hand, academicians regard the practicioners who do not understand linguistic issues. Thus, their opinion cannot be accepted theoritically (Sofyan, 2007b). Other factors, such as the dichotomy among the practitioners and the academicians in constructing and standardizing the EBM, are reflected in some different opinions: (1) the diversity in background of observers, (2) diverse generation either old or young, (3) different careers of the observers'. Because of the dichotomy that occurs among the observers, they ignore BM problems that have been complex. It is believed that BM will not be able to survive in the future as a language and it is soon to be extinc. Therefore, BM faces an ironical condition that should not happen, that is, that BM as one of the most widely used local languages still does not have standardized spelling.

\footnotetext{
${ }^{*}$ Corresponding Author.

E-mail Addresses: elbadrelkarim@yahoo.co.id (A. Badrudin), sofyanakhmad544@gmail.com (A. Sofyan).
} 
Another problem that occurs next to the absence of standardized EBM is that the materials for constructing in written form are very limited. The definite materials are caused by the writers' confusion in using the directive spelling. The process of BM writing depends on the writer's ability in writing which is hard to learn. Without standardized BM spelling, the development of language is hardly to be achieved and maximized. In 2002, there had been some efforts to standardize EBM by holding: (1)Workshop on EBM in 2002, (2) Conceptual Revision of EBM in 2003, (3) Socialization of EBM in 2005, (4) Consignmentof the revised EBM in 2011, and (5) Socialization of revised edition of EBM in 2012.

However, there were controversial issues to the EBM publication. Some people openly refused the publication by writing to the chief of language authority office of East Java (BBJT) and to the EBM composers through an article posted in Madura magazines such as Jokotole magazine and Pakem Maddhu magazine stating that they refused to use the EBM published by BBJT.

In general, the issues triggering controversy include: (1) vowel spelling / e / and / $\mathrm{\epsilon} /$, (2) vowel / a / spelling consisting of two allophones, namely [a] and [â], (3) Consonant spelling / k / and /? /, (4) spelling of voiced post-dental consonants $(/ \mathrm{d} /)$ and post-alveolar voices (/ D /), (5) writing of post-dental voiceless $(/ \mathrm{T} /)$ consonants, (6) spelling of consonant aspiration, and (7) spelling of sounds and sounds that emerge due to the affixation process.

\section{Research Method}

The method used in this research is descriptive qualitative method. Data collection was done by conducting indepth interviews with BM observers from various parties from 3 dialects (Sumenep, Pamekasan, and Bangkalan) (Penninga \& Hendriks, 1942). Description of interview results from 1 dialect area would then be discussed in the form of FGD which involved all informants from each dialect.

\section{Result and Discussion}

\subsection{The Spelling of Madurese Language of the Year 2003}

The 2003 Improved Generalized Spelling Guideline 2003-later reissued in 2008 (Balai Bahasa Surabaya, 2008) — is based on the results of the "Madurese Confirmation Workshop" (Balai Bahasa Surabaya, 2003). It was organized by Balai Bahasa Surabaya on December 31, 2002, which resulted in the formulation that the Madurese Spelling Concept of 1973 could be implemented with the following improvements.

- The vocal e peppet (/ a /) and e talèng (/ $€$ /) need to be marked or different symbols (e and è).

- The writing of vowel / a / is written with two symbols, namely $a$ for the front and front vowels for the lower-center vowel.

- The writing of hamzah or glottal sounds using apostrophes (..'..), while the velar sound ([k]) uses k.

- The conspired aspirated and unaspirated consonants are given different symbols.

- The sound of the transmitter ( $w, y$, and glotal) and other sounds that arise as a result of the affixation or affixing process are not written.

- The writing of the voiced post-dental consonant (/ d /) uses d (d point down), while the post-alveolar sounds (/ D /) uses d (d without the bottom).

- The writing of post-dental consonants voiceless (/ T/) using th.

\subsection{The Spelling of Madurese Language Revised Edition}

The General Guidelines for Improved Madurese Spelling as the revised edition published by East Java Language Center in 2012 are the result of the "Madurese Revised Consentation Spelling" which was held in Sumenep on 10-12 June 2011 (Balai Bahasa Provinsi Jawa Timur, 2012). In the revised consortium, there are still many controversies caused by the many comments and objections from EBM users. Many users of EBM find it difficult to use it. It is believed that it is caused by the use of many unnecessary symbols. EBM users expect the use of symbols (such as è, â, and ḍ) to be reduced as it is technically burdensome.

Responding to many comments and objections to EBM in 2003, the participants of the consignment were engaged in an exciting debate. The debates in the forum include: (1) vocal writing of e peppet (/ a /) and e talèng (/ € /), (2) vowel writing a, (3) glotting ([?]), (4) Consonant writing d, (5) the writing of post-dental sounds [T]), 
(6) the writing of sounds of aspiration, and (7) the writing of glossy, glottic sounds and other sounds that arise as a result from the affixation process. From the seven issues that became the debate, the first three problems easily reached agreement, while the last four problems led to debates. Three issues that easily reached agreement are as follows.

- The vocal e peppet (/ ə/) and e talèng (/ $€ /$ ) are written with different symbols, ie e and è.

- A vowel is written with two symbols a and a.

- a glottal ([?]) Is written with an apostrophe symbol (.....), while the velar sound is written with $\mathrm{k}$.

In BM, vocal e peppet and e talèng are different phonemes. Therefore, both types of vowels are distinguishable or can be contrasted on a minimal pair (Sofyan, 2010). Therefore, both types of vowels must be given different symbols, is e and è. Actually, it is proposed that for e peppet and e talèng use 1 letter. It is actually written in the same letter. BM users can easily tell the difference in meaning of words based on the context of the sentence. The goal is to simplify the use of symbols, making it easier to type.

The use of two symbols for the vowel / a / a for the front and front vowels for the bottom-center vowel is based on practical reasons (for ease of reading) and to avoid writing errors. In many cases, at the time of writing $\mathrm{BM}$, peop le with less control over the phonemic problems of BM tend to use the e symbol for sound []. Actually, there is a suggestion that for vowel a use 1 letter, that is a. It does not need to be distinguished into a and a. Therefore, the writing technically feels very difficult.

The hamzah or glottal sounds use apostrophes (....), while the velar sound ([k]) is written with the letter k. The basic consideration is that in addition to being a phoneme different from [k], the distribution is not only at the end of the word but also in the middle of the word and between the two vowels. With such distribution, if glotting is symbolized by the letter $\mathrm{k}$, it will be difficult to read because it does not appear to be the final consonant of the previous tribe but appears to be the initial consonant of the next term.

The debates that occurr with respect to: consonant writing d, writing of dubious post-dental sound ([T]), the writing of sounds of aspiration, and the writing of glossy, glottic sounds, and other sounds that arise as a result of the affixation process are as follows.

- Concerning the writing of the consonant $d$, one party is of the opinion that the consonant $d$ should be distinguished between $\mathrm{d}$ ( $\mathrm{d}$ without the underscore) and $\mathrm{d}$ ( $\mathrm{d}$ point below), while the other party is of the opinion that both do not need to be distinguished and use $\mathrm{d}$ (dot under).

- Regarding the writing of the consonant th, for the unbounded post-dental sound ([T]), one party thinks to be written with $t$ ( $t$ the bottom point), while the other party thinks to be written with th.

- Concerning the writing of conspired voiced conspiracies ([bh], [dh], [Dh], [gh], and [jh]), some argue that the writing of the sounds is not necessarily distinguished from the voices of unpopular voices; Or if it should be distinguished, should be used 1 letter does not use 2 letters as used on the concept of EYD, namely: bh, dh, đh, gh, and jh.

- Regarding the writing of gliders, glotters, and other sounds that arise as a result of the affixation process, one party argues to be written, while the other party contends not to be written.

\subsubsection{Consonant Writing ([d])}

In the Revised Consignment of Spelling, it is decided that a voiced post-dental sound (d) is used by the hunder $\mathrm{d}$ (d without the bottom), while the voiced post-alveolar sound ([D]) is used d (d the bottom point). In the BM, between the sounding post-dental sounds ([d]) as in the word [dâlâ?] 'Sodomy' with the voiced post-alveolar sound ([D]) as in [DâDâ] 'chest', [Dâpa?], And [manDi] 'bathing' are two different phonemes. Both sounds are encountered in minimal pairs or in similar pairs. Therefore, at EBM in 2003 the two sounds are given different symbols, is d ( $\mathrm{d}$ point down) for the voiced post-dental sound and $\mathrm{d}$ (d without the bottom) for the sounding post-alveolar sound. The consideration is that between the two consonant sounds, the very productive use is /D/, whereas /d/ its use is very limited, it is only found in certain words.

In Consignment of the Revised Spelling, it is proposed that both sounds should be used in 1 letter, $\mathrm{d}$. However, the proposal was strongly opposed by participants with a background as practitioners. Therefore, it is proposed to continue using symbols such as EBM in 2003; i.e. to be technically not difficult, if it is necessary to distinguish the writings, it should be given a special sign that consonants are more limited use ie / d / using d (d point below), while for post-alveolar voiced consonants ([D] ) is simply used d (d without the mark).

Because what is agreed on in the Revised Consignment of Spelling is a dubbed post-dental sound $(\mathrm{d} d)$ used $\mathrm{d}$ (d without the bottom), whereas a voiced post-alveolar sound ([D]) is used ḍ (d point down), technically typing 
EBM Revised edition is even more difficult when compared to EBM in 2003. Almost all consonant d in BM is a voiced post-alveolar consonant, so with the agreement almost every letter $\mathrm{d}$ should use $\mathrm{d}$ ( $\mathrm{d}$ point below).

\subsubsection{Consonant Writing ([T])}

Consonant writing ([T]) remains like EBM 2003, i.e. using th (letter $t$ and $h$ ). For dental noisy sounds ([t]) is used the letter $\mathrm{t}$, whereas post-dental sounds are not used ( $\mathrm{t}$ ) used th ( $\mathrm{t}$ and $\mathrm{h}$ ). In BM, between the soundless dental sound ([t]) with the post-dental voiceless ([T]) is a different phoneme, so it is given a different symbol. The use of th symbol for consonant / $\mathrm{T} /$ is technically acceptable and easier than using the letter $\mathrm{t}$ ( $\mathrm{t}$ the bottom point).

\subsubsection{The Writing of Voiced Consonant}

The writing of consonant voiced is not aspirated ([b], [d], [g], and [j]) and the sound of aspiration sounds ([bh], [dh], [Dh], [gh], and [jh]) remain as EBM 2003. In BM, voiceless consonant and voiced consonants with conspiratorial consonants are two different phonemes. The reason is that both types of sounds are distinguishable or can be contrasted on a minimal pair. Therefore, both types of sounds are given different symbols. The symbols for technical sounding which are technically easier to do are bh, dh, gh, and dh.

\subsubsection{The Writing of Sounds Due to Affixation Process}

In contrast to the 2003 EBM that the sound of the transmitter is not written (Balai Bahasa Surabaya, 2003), in EBM 2012 every sound of the transmitter should be written, is written w, y, and '(apostrophes) (Balai Bahasa Provinsi Jawa Timur, 2012). If in EBM 2003 "The glowing and glottal sounds that arise as a result of the affixation process are not written", in EBM 2012 "Glowing, glotting, and other sounds that arise as a result of the affixation or advisory process must be written".

A w sound occurs when the base form ends with a vowel $/ o /$ or $/ u /$ is approximated by the suffix $\{-\mathrm{a}\},\{$-è $\}$, or $\{-i\}$. A j-sound appears when: (a) the basic form ending with the vowel / è / or / $\mathrm{i} / \mathrm{is}$ approached by the suffix $\{$-a $\},\{$-aghi $\},\{$-ana $\}$; (B) the prefix $\{\mathrm{e}-\}$ joins the basic form with an initial phoneme or a. Glotting ([?]) Occurs when the base form ends with the vowel /a/ approached by the suffix $\{-\mathrm{a}\},\{$-aghi $\},\{-$ ana $\}$ (Wibisono, Sofyan, Suyanto, \& Izzat, 2006).

In terms of grammar, the appearance of the transmitter ([w], [y], and [?]) is usually not written because its appearance is predictable or known to every speaker. For a glottal sound, in addition to its appearance it can be predicted or known by every speaker, if the sound is written will cause different words to be written together that can cause error meaning. For example nompa>nompa'a 'will / almost spill' and pump '>nompa'a' will rise / drive ', ngala'a' will budge 'and ngala'>ngala'a 'will take', as well >Èkala'aghi 'defeated' and when '>èkala'aghi' was taken.

Good spelling recognition is based on three basic norms or considerations, namely: (1) theoretical considerations, that is not deviating much less contrary to linguistic theories, especially the theory of the BM phoneme; (2) practical considerations, that is, it is easy to read and notice the peculiarities contained in the DGH; And (3) technical considerations, meaning that writing can be done relatively easily and quickly, by using more simple symbols (Samsuri, 1987).

\section{Conclusion}

In doing the spelling standardization, one thing we need to note is that spelling of a language is not related to the determination of a standard dialect in that language. That is, spelling recognition is not solely based on the habitual use of spelling in standard dialects. In the case of DGH, although the standard dialect of Sumenep dialect is spoken, the standardization of BM spelling cannot be based solely on the prevailing spelling practice in the Sumenep dialect.

\section{References}

Alwi, H. (2011). Kebijakan keunikan tentang bahasa daerah. In D. Sugono, \& A. R. Zaiden (Eds.), Bahasa daerah dan otonomi daerah. Jakarta: Pusat Bahasa Dearah dan Pendidikan Nasional. 
Balai Bahasa Provinsi Jawa Timur. (2003). Pedoman umu ejaan bahasa Madura yang disempurnakan. Surabaya: Balai Bahasa Provinsi Jawa Timur.

Balai Bahasa Provinsi Jawa Timur. (2008). Pedoman umum ejaan bahasa Madura yang diesempurnakan. Surabaya: Balai Bahasa Provinsi Jawa Timur.

Balai Bahasa Provinsi Jawa Timur. (2012). Pedoman umum ejaan bahasa Madura yang disempurnakan (Revised Edition ed.). Surabaya: Balai Bahasa Provinsi Jawa Timur.

Lauder, M. R. (2004). Pelacakan Bahasa Minoritas dan Dinamika Multikultural. Simposium Kajian Bahasa, Sastra, dan Budaya Austronesia III. Denpasar.

Marsono. (2003). Bahasa, sastra, seni dan budaya Jawa sebagai aset wisata. Pidato Pengukuhan Guru Besar. Yogyakarta.

Penninga, H., \& Hendriks, H. (1942). Madurese in een Maand Practische Hanleiding voor het Aanleren van deMadurese Tall. Semarang: G.T.C van Dorp \& Co. N.V.

Samsuri. (1987). Analisis bahasa. Jakarta: Erlangga.

Sofyan, A. (2007a). Dialek dan Tingkat Tutur dalam Bahasa Madura. Medan Bahasa, I(1).

Sofyan, A. (2007b). Beberapa keunikan linguistik bahasa Madura. Humaniora, XIX(3).

Sofyan, A. (2007c). Proses penyusunan ejaan bahasa Madura yang disempurnakan. Kultur, I(2).

Sofyan, A. (2007d). Upaya pembukuan ejaan bahasa Maduran dan pertimvangan terhadap persolan yang diperdebatkan. Mozaik, 2(I).

Sofyan, A. (2010). Fonologi bahasa Madura. Humaniora.

Wibisono, B., Sofyan , A., Suyanto, B., \& Izzat, A. (2006). Kodifikasi morfologu bahasa Madura. Surabaya: Balai Bahasa Surabaya. 